\title{
Effects of cattle trampling and mechanical seedbed prep- aration on grass seedling emergence
}

VON K. WINKEL AND BRUCE A. ROUNDY

\section{Abstract}

Cattle trampling has been recommended to bury seeds and encourage seedling establishment but has not been compared with traditional seedbed preparation techniques. We compared seedling emergence of broadcast-seeded 'Vaughn' sideoats grama [Bouteloua curtipendula (Michx.) Torr.], 'A-130' blue panic (Panicum antidotale Retz.), 'A-68' Lehmann lovegrass (Eragrostis lehmanniana Nees), and 'Cochise' atherstone lovegrass (Eragrostis lehmanniana Nees $X$ E. tricophera Coss and Dur.) on lightly and heavily trampled seedbeds with that on undisturbed, land imprinted, and root-plowed or ripped seedbeds. We seeded and applied the trestments prior to summer rains on a sandy loam soil in southern Arizona for 3 years. In $\approx$ wet year (1987) when surface soil water was estimated to be available for at least 24 consecutive days, heavy trampling and land imprinting increased emergence of blue panic and land imprinting increased emergence of Cochise lovegrass. In that year, lovegrass emergence was high even on undisturbed plots. In a moderately wet year (1988), surface soil water was available for periods of 6 9 days during seedling emergence and greater disturbance, either by heavy trampling, land imprinting and/or root plowing or ripping produced higher emergence than light trampling and nondisturbance. In a dry year (1989), surface soil water was available for periods of 2-3 days and seedling emergence was low and generally similar for all treatments. Sideoats grama emergence was low all 3 years, but was highest in 1988 when initial thunderstorms were followed closely by subsequent storms. Seedbed disturbance by cattle and mechanical methods may enhance revegetation in the Southwest in years of moderate precipitation but may be unnecessary in wet years or futile in dry years, depending on species and soib.

Key Words: land imprinting, root plowing, sideoats grama, blue panic, Lehmann lovegrass, Cochise lovegrass, range revegetation

Livestock trampling has been recommended as a way to help bury seeds and increase seedling emergence in rangeland revegetation (Plummer et al. 1955, Hormay 1970, Pearson and Ison 1987, Vallentine 1989). However, there are few data available to evaluate the use of livestock as a seedbed preparation technique. In Nevada, moderate trampling increased emergence of perennial grasses, but decreased emergence of perennial forbs on specific seedbed microsites (Eckert et al. 1986). Heavy trampling decreased perennial grass emergence, but increased emergence of sagebrush and annual forbs on certain microsites.

Comparisons between trampling and other techniques are needed to determine if it is a viable seed bed preparation technique. Mechanical seedbed preparation techniques used in the Southwest include root plowing and land imprinting. Rootplowing has been successful in controlling woody plants (Fisher et al. 1959) and produces a highly disturbed seedbed which may bury broadcast seeds (Jordan 1981). Revegetation success on root-plowed seedbeds has been reported by Allison and Rechenthin (1956), Fisher et al. (1959), Herbel et al. (1973) and Nelson and Gabel (1987).

\footnotetext{
At the time of this research, authors were graduate research associate and associate professor, School of Renewable Natural Resources, University of Arizona, Tucson, Arizona 85721 . Winkel is currently scientist EG and G Energy Measurements, P.O. Box 1912 M/S P-03, Las Vegas, Nevada 89125.

Research was funded by the USDA Rangeland Research Grants program. Published as Arizona Agricultural Experiment Station paper 7188. The authors wish to thank John King for providing the study site

Manuscript accepted 30 May 1990
}

The land imprinter was developed to increase revegetation success on semiarid rangelands by concentrating soil water in furrows (Dixon and Simanton 1980). Few studies have been conducted which compare land imprinting with other seedbed preparation techniques. In southern Arizona, land imprinting resulted in fewer broadcast or drill-seeded grass plants than did railing or disking, probably because it did not reduce competition from creosotebush [Larrea tridentata (DC.) Coville] (Cox et al. 1986). Haferkamp et al. (1987) reported seedling emergence of crested wheatgrass (Agropyron desertorum [Fisch. ex Link) Shult.] was nearly twice as high with imprinting compared to drilling on loose, disked seedbeds, but 2-4 times more seedlings emerged from drilling than imprinting on firm, unprepared seedbeds. Clary (1989) reported greater density, cover and production of seeded species from imprinting a burned sagebrush community as compared to seeding with a rangeland drill. He suggested the difference was related to increased bulk densities or imprinted soil, decreased wind erosion, and greater seed-soil contact. Our objective was to compare the effects of light and heavy cattle trampling, rootplowing, land imprinting or ripping, and nondisturbance on seedling emergence of warm-season grasses.

\section{Methods}

\section{Study Area}

The study was conducted on the Anvil ranch, about $65 \mathrm{~km}$ southwest of Tucson, Ariz. The study site is on the east slopes of the Baboquivari mountains at an elevation of $1,027 \mathrm{~m}$. The soil is a sandy loam (fine, mixed, thermic Ustollic Haplargids). The site is on the edge of the Chihuahuan semidesert grassland subresource area (Jordan 1981), with major plant species consisting of mesquite (Prosopis juliflora Swartz), snakeweed (Gutierrezia sarothrae Pursh), various cacti, and native grasses including Arizona cottontop [(Digitaria californica (Benth.) Henr.)] and purple 3-awn (Aristida purpurea Nutt.).

The climate is characterized by hot summers and cool winters. Average annual precipitation for the past 30 years, obtained 17.7 $\mathrm{km}$ from the site, is $328 \mathrm{~mm}$, of which $60-70 \%$ falls between July and November (U.S. Dept. Commerce 1987).

\section{Treatment Application}

The experiment was a split plot with 5 seed bed treatments and 4 species applied in 4 blocks on each of 3 years. Years were randomized within blocks and each block per year included 20 plots, which were randomly assigned the 20 treatment-species combinations.

All plots used in a particular year were treated with a combination of picloram (4-amino-3,5, 6-trichloropicolinic acid) at 0.6 $\mathrm{kg} / \mathrm{ha}$ and 2,4,D [(2, 4-dichlorophenoxy) acetic acid $]$ at $2.2 \mathrm{~kg} / \mathrm{ha}$ to kill snakeweed, and glyphosate [(N- (phosphonomethyl)] glycine) at $2.2 \mathrm{~kg} /$ ha to kill native grasses. Scattered mesquite trees were cut and removed.

Five seedbed preparation treatments were applied in June or early July (before summer rains) on 6 by $6-\mathrm{m}$ plots: (1) no disturbance, (2) light cattle trampling, (3) heavy cattle trampling, (4) land imprinting, and (5) root plowing or ripping. Lightly trampled plots were treated by leading a 300-500 kg steer or heifer around each plot until a density of about 10 hoof prints per $\mathrm{m}^{2}$ was obtained. 
Heavily trampled plots were enclosed with an electric fence, and five $300-500 \mathrm{~kg}$ steers or heifers were herded around each plot for approximately 20 minutes. Plots were land imprinted with a Dixon land imprinter composed of 1 directional and 1 nondirectionalgeometric angle iron form welded on separate 1 by $1-\mathrm{m}$ cylinder capsules. Total weight of the imprinter was approximately 5 metric tons and it produced imprints approximately $5-7-\mathrm{cm}$ deep in this soil.

Root-plowed plots were treated with a root plow in 1987 that was pulled through each plot at a depth of $15-20 \mathrm{~cm}$. Because of root plow breakage in 1988 and 1989, plots in those years were treated with a ripper. The ripper had 3 shanks about $60-\mathrm{cm}$ apart and was pulled through the soil in each plot 5 times at a depth of $15-20 \mathrm{~cm}$ to thoroughly disturb the seedbed. The composition of the seedbeds with root-plowed and ripped plots was similar. Seedbeds were prepared between 1 and $8 \mathrm{July}$ in 1987, 14 and 17 June in 1988, and 29 May and 5 June in 1989.

Seeds of 'Vaughn' sideoats grama (Bouteloua curtipendula (Michx.) Torr.), 'A-130' blue panic (Panicum antidotale Retz.), 'A-68' Lehmann lovegrass (Eragrostis lehmanniana Nees), and 'Cochise' atherstone lovegrass (Eragrostis lehmanniana Nees $X E$. tricophera Coss and Dur.) were either sown with a hand-held 'Cyclone' seeder, or mixed with No. 60 blasting sand and hand broadcast onto all plots at a rate of 1.2 million pure live seeds per hectare. All plots except plowed plots were seeded before treatment application while plowed plots were seeded immediately after treatment.

\section{Data Collection}

Seedling densities were recorded when seedlings were about 2-4-cm tall. This corresponded with 18 August 1987, 1 August 1988 , and 22 August 1989. Each plot was sampled with $1 / 16-\mathrm{m}^{2}$ quadrats uniformly spaced across the plot in 2 transects of several quadrats each. Number of quadrats (subsamples) varied from 20-40 per plot for the lovegrasses, and 40-80 quadrats for sideoats grama and blue panic. Quadrat numbers were increased for a given species and year when densities were low and decreased when densities were high.

Percent cover of indigenous forbs, annual and perennial grasses, and bare ground and litter was recorded beginning on 15 September 1987, 26 September 1988, and 8 September 1989. Each plot was sampled with a 10-point pin frame uniformly spaced across the plot in 2 transects of 5 placements each, for a total of 100 points per plot. Frequency data were derived from density data to determine differences in distribution of the seeded species.

Soil water in the top 1-3 cm was measured in selected undisturbed, imprinted, and heavily trampled plots with Colman soil moisture cells (Colman and Hendrix 1949) in 1988 and 1989. Precipitation was measured on site with a tipping-bucket rain gauge, and soil water and precipitation data were recorded with a Campbell Scientific Instruments CR-10 datalogger. Soil from the top $20 \mathrm{~cm}$ of several plots was analyzed for percent water content at $-0.03,-0.10,-0.30$, and $-1.50 \mathrm{MPa}$ matric potential with a pressure plate. Soil water was considered available for germination and growth when volumetric water content was above 0.09 , which corresponds to a matric potential of $-0.1 \mathrm{MPa}$.

\section{Statistical Analysis}

Because numbers of quadrats or subsamples counted varied among years for some species, seedling density data were analyzed initially for significance of main effects and interactions by calculating approximate $\mathrm{F}$ ratios according to the procedure of Steel and Torrie $(1980)$. Significant $(P<0.01)$ year-species-treatment interaction justified analysis of variance and LSD mean separation $(P<0.05)$ of treatments separately for each species for each year. In those analyses, conventional $F$ ratios were calculated since the
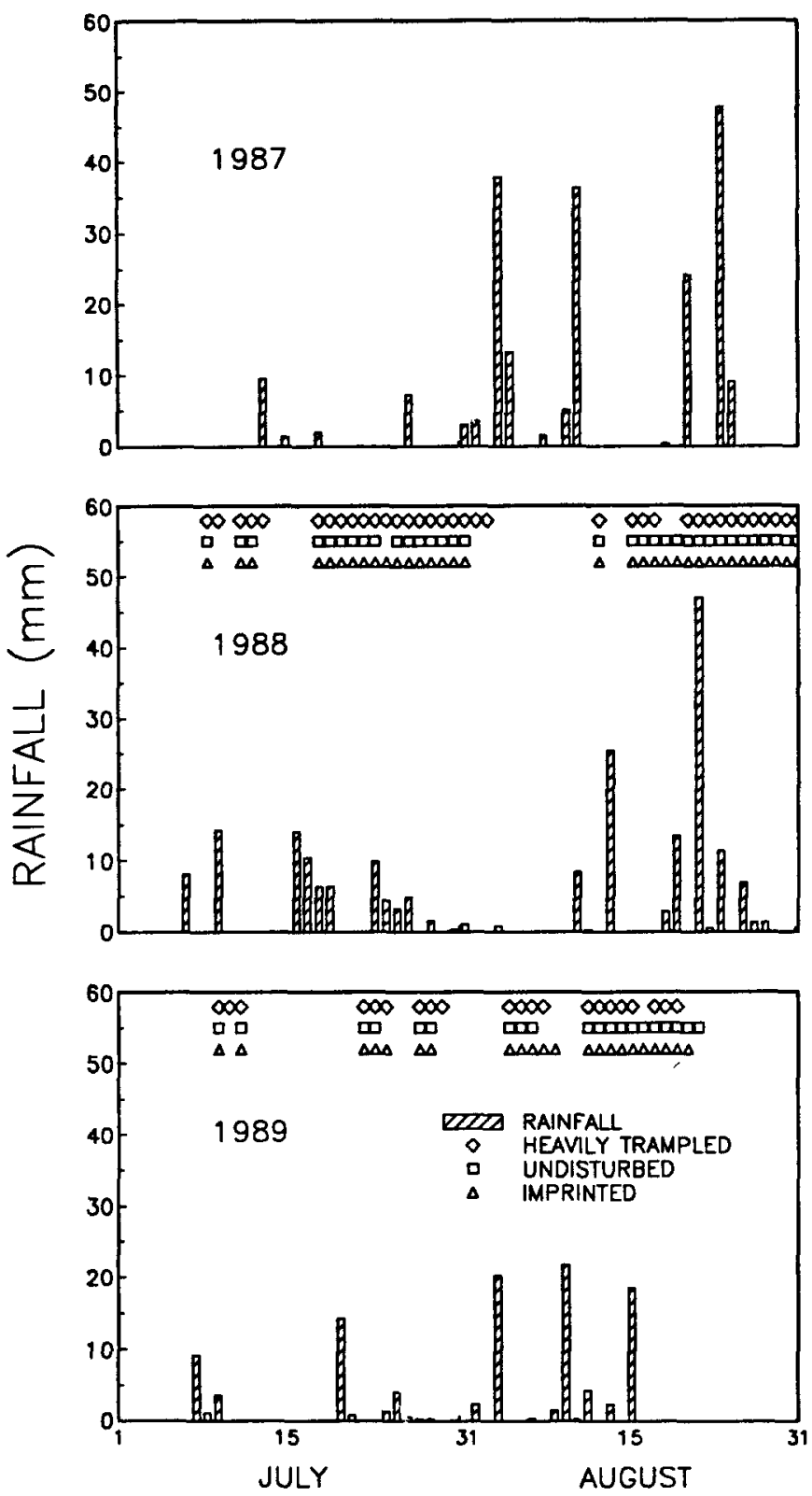

Fig. 1. Daily rainfall (vertical bars) for July and August 1987, 1988, and 1989 at the Anvil Ranch, southern Arizona; and lengths of wet and dry periods in the upper $1-3 \mathrm{~cm}$ of the seedbed in relation to year and seedbed preparation treatment. Periods of soil water content (vol/rol) $\geq 0.09$ P-0.1 MPa matric potential) are indicated by symbols and dry periods are represented by blank spaces between symbols.

total number of subsamples were equal for a given year and species. Analysis of variance was performed on the arcsin square root of percentage data both for cover and frequency.

\section{Results}

\section{7}

Consistent summer rainfall began on 21 July and continued with high frequency and intensity until 25 August (Fig. 1). Although no soil water data were collected during 1987 , the surface soil remained wet from approximately 4 to 28 August. All species had high emergence except sideoats grama (Fig. 2). Blue panic had little emergence on undisturbed and lightly trampled plots, moderate emergence on root-plowed plots, and high emergence on heavily trampled plots. The lovegrasses had high emergence for all treat- 

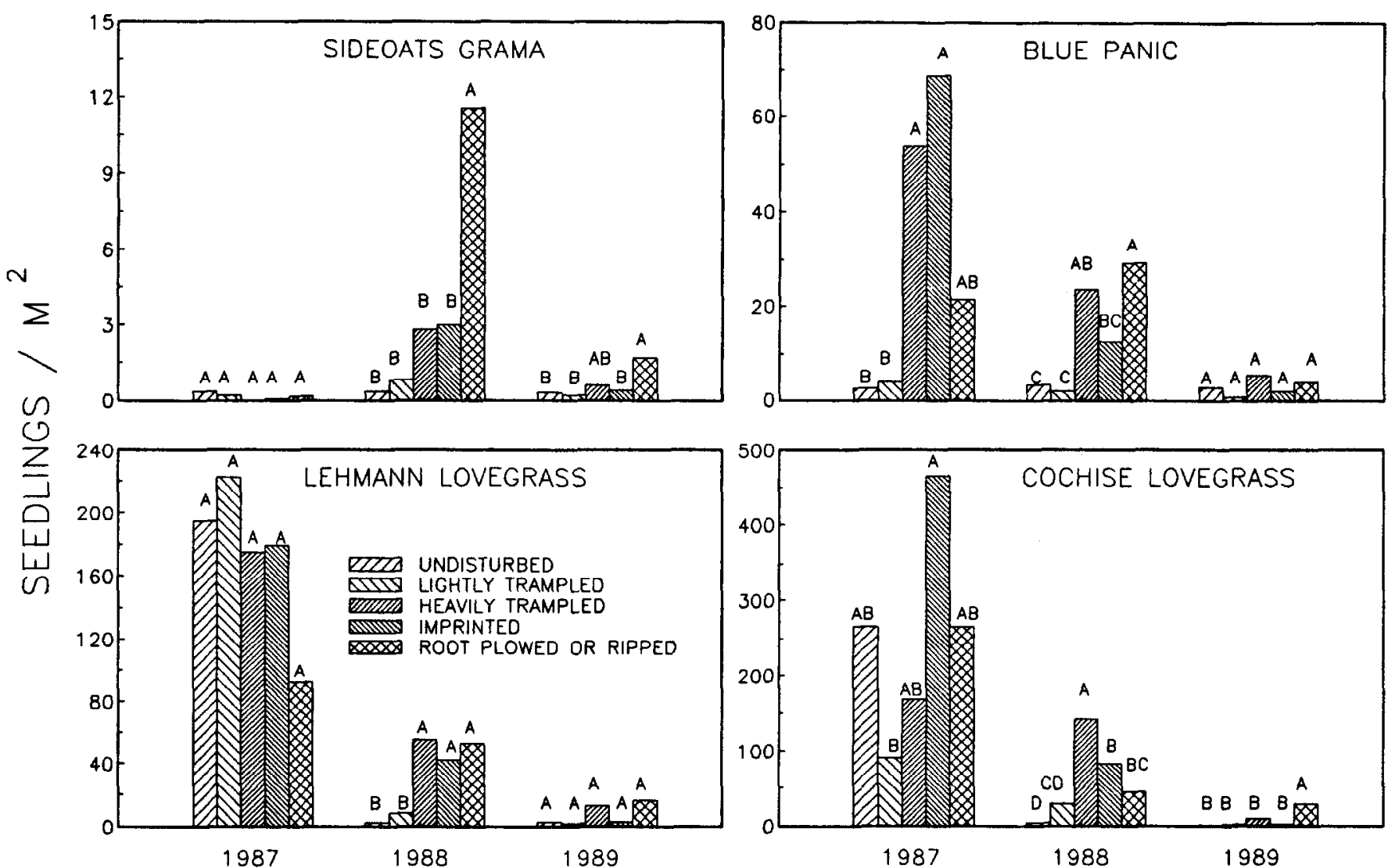

Fig. 2. Seedling density of broadcast-seeded sideoats grama, blue panic and Lehmann and Cochise lovegrass in relation to seedbed preparation treatments done on 3 years on a loamy upland range site in southern Arizona. Means for a species within a treatment year with the same letter are not significantly different ( $P>0.05)$.

ments but responded to them differently. Lehmann lovegrass had a trend toward lower emergence on root-plowed plots than on the other treatments. Cochise lovegrass had greatest emergence on imprinted plots, lower emergence on undisturbed, heavily trampled, and root-plowed plots, and least emergence on lightly trampled plots.

\section{8}

Thunderstorm activity began on 7 July and continued with fairly high frequency until 28 August (Fig. 1). Although number of days with rainfall during July and August was higher in 1988 (15 in 1987, 25 in 1988), storms were generally smaller and the seedbed did not stay wet as long as in 1987 . Starting on 17 July, soil water was available in the surface soil for about 6 days, unavailable for a day or less and then available for another 6-9 days. Most seedlings emerged during these wet periods. Heavily trampled and imprinted plots generally had available water for 1 to 2 days longer than undisturbed plots.

Seedling densities were generally higher on heavily trampled, imprinted, or ripped plots than on undisturbed or lightly trampled plots (Fig. 2). Sideoats grama density was highest on ripped plots. Blue panic density was highest on ripped and heavily trampled plots followed by imprinted plots. Lehmann lovegrass densities were similar on ripped, imprinted, and heavily trampled plots. Cochise lovegrass densities were highest on heavily trampled plots, followed by imprinted and ripped plots. The lovegrasses had much higher emergence than blue panic and sideoats grama for all disturbance treatments.

\section{9}

Summer rainshowers in 1989 were less frequent and intense than in either 1987 or 1988 (Fig. 1). Initial and subsequent storms in July were separated by a 10-day dry period. Periods of surface-soil water availability during emergence in July were only 2-3 days long. Heavily trampled and imprinted plots had similar periods of available water in the surface soil that were up to 14 hours longer than in undisturbed plots. Emergence was low for all species and generally similar for the different seedbed treatments (Fig. 2). Ripping slightly increased emergence of sideoats grama and Cochise lovegrass over that of the other treatments.

\section{Seedling Frequency}

There was a significant interaction between year and treatment for frequency of seeded species (Table 1). Seedlings were most evenly distributed on seedbeds prepared by heavy trampling, imprinting and root plowing or ripping. Distribution was moderate on undisturbed and lightly trampled plots in 1987, and limited in 1988 and 1989. Distribution across treatments was greatest for the lovegrasses, followed by blue panic and then sideoats grama.

\section{Cover of Indigenous Grasses}

Analysis of variance for both bare ground and litter cover indicated significant $(P<0.05)$ treatment and year effects but the treatment-year interactions were not significant $(P<0.05)$. Root plowing or ripping and heavy trampling resulted in more bare ground than the other treatments (Table 2). More bare ground was exposed in 1989 than in 1988 (Table 3). Heavily trampled, imprinted and root-plowed or ripped plots had significantly less $(P<0.05)$ litter cover than lightly trampled and undisturbed plots. There was significantly more litter in 1989 than in the other 2 years, probably as a result of a gradual build-up of litter associated with cattle exclusion.

The 4 most common indigenous grasses on the plots included an annual lovegrass (Eragrostis arida Hitchc.), feather fingergrass 
Table 1. Frequency (\% occurrence in subsample quadrats) of broadcastseeded sideoats grama, blue panic, and Lehmann and Cochise lovegrass in relation to year of seeding and seedbed preparation treatment on a loamy upland range site in southern Arizona.

\begin{tabular}{|c|c|c|c|c|}
\hline \multirow[b]{2}{*}{$\begin{array}{l}\text { Year and seedbed } \\
\text { treatment }\end{array}$} & \multicolumn{4}{|c|}{ Species } \\
\hline & $\begin{array}{l}\text { Sideoats } \\
\text { grama }\end{array}$ & $\begin{array}{l}\text { Blue } \\
\text { panic }\end{array}$ & $\begin{array}{l}\text { Lehman } \\
\text { lovegrass }\end{array}$ & $\begin{array}{l}\text { Cochise } \\
\text { lovegrass }\end{array}$ \\
\hline 1987 & \multicolumn{4}{|c|}{ - } \\
\hline $\begin{array}{l}\text { Undisturbed } \\
\text { Lightly trampled } \\
\text { Heavily trampled } \\
\text { Land imprinted } \\
\text { Root plowed }\end{array}$ & $\begin{array}{l}2 \mathbf{a}^{\prime} \\
1 \mathrm{a} \\
0 \mathbf{a} \\
0 \mathbf{a} \\
1 \mathbf{a}\end{array}$ & $\begin{array}{l}11 \mathrm{c} \\
12 \mathrm{c} \\
74 \mathrm{a} \\
66 \mathrm{a} \\
37 \mathrm{~b}\end{array}$ & $\begin{array}{l}64 \mathrm{ab} \\
61 \mathrm{ab} \\
71 \mathrm{ab} \\
81 \mathrm{a} \\
50 \mathrm{~b}\end{array}$ & $\begin{array}{l}63 \mathrm{~b} \\
63 \mathrm{~b} \\
61 \mathrm{ab} \\
90 \mathrm{a} \\
75 \mathrm{ab}\end{array}$ \\
\hline $\begin{array}{l}1988 \\
\text { Undisturbed } \\
\text { Lightly trampled } \\
\text { Heavily trampled } \\
\text { Land imprinted } \\
\text { Ripping }\end{array}$ & $\begin{array}{l}2 \mathrm{bc} \\
3 \mathrm{~b} \\
13 \mathrm{~b} \\
11 \mathrm{~b} \\
30 \mathrm{a}\end{array}$ & $\begin{array}{l}13 \mathrm{~b} \\
10 \mathrm{~b} \\
48 \mathrm{a} \\
34 \mathrm{a} \\
53 \mathrm{a}\end{array}$ & $\begin{array}{l}11 b \\
21 b \\
64 a \\
51 a \\
61 a\end{array}$ & $\begin{array}{l}12 \mathrm{c} \\
36 \mathrm{bc} \\
82 \mathrm{a} \\
56 \mathrm{ab} \\
55 \mathrm{ab}\end{array}$ \\
\hline $\begin{array}{l}1989 \\
\text { Undisturbed } \\
\text { Lightly trampled } \\
\text { Heavily trampled } \\
\text { Land imprinted } \\
\text { Ripping }\end{array}$ & $\begin{array}{l}1 \mathrm{~b} \\
1 \mathrm{~b} \\
3 \mathrm{ab} \\
3 \mathrm{ab} \\
6 \mathrm{a}\end{array}$ & $\begin{array}{r}9 a \\
4 a \\
16 a \\
20 a \\
18 a\end{array}$ & $\begin{array}{l}5 \mathrm{~b} \\
9 \mathrm{~b} \\
39 \mathrm{a} \\
15 \mathrm{ab} \\
36 \mathrm{a}\end{array}$ & $\begin{array}{r}3 b \\
5 b \\
21 a \\
8 b \\
45 a\end{array}$ \\
\hline
\end{tabular}

'Means in a column within a year with the same letter are not significantly different $(P>0.05)$.

(Chloris virgata Swartz), sixweeks needle grama (Bouteloua aristidoides (H.B.K.) Griseb.), and Rothrock grama (Bouteloua rothrockii Vasey). There was no significant $(P>0.05)$ difference in cover for these species for any of the seedbed treatments (Table 2). There was less annual lovegrass and feather fingergrass in 1989 than in 1987 and 1988 (Table 3).

\section{Discussion}

Differences in seedling emergence among years and treatments were related to precipitation patterns and periods of available water. Seedling emergence was highest for all species except sideoats grama in 1987 when surface-soil water was estimated to be available for about 24 consecutive days. The lovegrasses had high emergence from all treatments in that year while blue panic had greater emergence on the more disturbed seedbeds. The low density of sideoats grama in 1987 may be related to its rapid germination (24-48 hours-Simanton and Jordan 1986) and possible desiccation during the 12-day drying period after initial rainstorms (Fig. 1). The other species require a longer period of available water to germinate and apparently only germinated in early August during consistent rainfall.

The greater emergence of the small-seeded lovegrasses com-
Table 3. Percent cover of bare ground, litter, and 4 indigenous grasses in 1987, 1988, and 1989 on a loamy upland range site in southern Arizona.

\begin{tabular}{|c|c|c|c|}
\hline \multirow[b]{2}{*}{ Parameter } & \multicolumn{3}{|c|}{ Year } \\
\hline & 1987 & 1988 & 1989 \\
\hline & \multicolumn{3}{|c|}{$\ldots---$ Cover $(\%)-\ldots-\ldots$} \\
\hline Bareground & $45 \mathrm{ab}^{\mathrm{l}}$ & $33 \mathrm{~b}$ & 54 a \\
\hline Litter & $12 \mathrm{~b}$ & $16 \mathrm{~b}$ & $33 \mathbf{a}$ \\
\hline Annual lovegrass & $10 \mathrm{a}$ & $11 \mathrm{a}$ & $\mathbf{0 b}$ \\
\hline Feather fingergrass & 5 a & 9 a & $0 \mathrm{~b}$ \\
\hline Six weeks grama & $2 \mathrm{a}$ & $4 a$ & I a \\
\hline Rothrock grama (seedlings) & $1 \mathbf{a}$ & $0 \mathrm{~b}$ & $1 \mathbf{a}$ \\
\hline
\end{tabular}

IMeans in a row with the same letter are not significantly different $(P>0.05)$.

pared to the larger-seeded blue panic on the undisturbed plots and the greater emergence of blue panic on the more disturbed seedbeds in 1987 may have been due to greater seed-soil contact. Heavy trampling, land imprinting, and root plowing buried more seeds than nondisturbance or light trampling (Winkel et al. 1991). However, many seeds were buried by summer rains, even on undisturbed and lightly trampled plots. Seedling emergence from surface-sown seeds on bare ground in a greenhouse study was much greater for Cochise lovegrass than for sideoats grama and blue panic (Winkel 1990). A lower trend in emergence of Lehmann lovegrass on root-plowed plots in 1987 may have been related to excessive seed burial. Root plowing buried at least $60 \%$ of the Lehmann lovegrass seeds too deep for seedling emergence (Winkel et al. 1991).

Greater seedbed disturbance by heavy trampling, land imprinting, or ripping produced greater seedling emergence than no disturbance or light trampling in a moderately wet year (1988). That was the only year that sideoats grama produced an acceptable stand of seedlings, and this occurred on the ripped plots. Ripping buried twice as many sideoats grama seeds at a depth from which seedlings could emerge than did the other treatments (Winkel et al. 1991). Successful emergence of sideoats grama in this year was probably related to more consistent initial rainfall and soil water availability at the start of the rainy season than occurred in 1987 or 1989. The greater seedling emergence of all species on the more disturbed seedbeds in 1988 was probably related to greater seed burial on these seedbeds (Winkel et al. 1991) and a slightly longer period of available water, at least for the imprinted and heavily trampled plots. In 1988, there were significant correlations between percentage of seeds buried immediately after treatment (Winkel et al. 1991) and seedling emergence for blue panic $\left(r^{2}=0.99, P=\right.$ 0.003), Lehmann lovegrass $\left(r^{2}=0.99, P=0.006\right)$ and Cochise lovegrass $\left(r^{2}=0.97, P=0.017\right)$. There were also significant correlations between percent of seeds buried after a $35-\mathrm{mm}$ rain and seedling emergence for sideoats grama $\left(r^{2}=0.99, P=0.001\right)$ and blue panic $\left(r^{2}=0.80, P=0.004\right)$. None of these correlations were significant $(P<0.05)$ in 1987 when soil water was available for a longer

Table 2. Effects of seedbed treatment applied before summer rains on a loamy upland range site in southern Arizona on percent cover of bare ground, litter and 4 indigenous grasses after the summer rainy season. Values are means of 3 years $(1987,1988,1989)$.

\begin{tabular}{|c|c|c|c|c|c|}
\hline \multirow[b]{2}{*}{ Parameter } & \multicolumn{5}{|c|}{ Seedbed treatment } \\
\hline & Undistrubed & Lightly trampled & Heavily trampled & Imprinted & Root plowed or pitted \\
\hline & & & -- Cover $(\%)--$. & , & -1 \\
\hline Bare ground & $36 \mathrm{~b}$ & $36 \mathrm{~b}$ & $52 \mathrm{a}$ & $41 \mathrm{~b}$ & $55 \mathrm{a}$ \\
\hline Litter & $27 a$ & $27 a$ & $16 \mathrm{~b}$ & $19 \mathrm{~b}$ & $15 \mathrm{~b}$ \\
\hline Annual lovegrass & $5 a$ & $7 a$ & $8 a$ & $9 a$ & $7 \mathrm{a}$ \\
\hline Feather fingergrass & $3 \mathbf{a}$ & $4 \mathrm{a}$ & $5 \mathrm{a}$ & $5 a$ & $6 a$ \\
\hline Six weeks grama & $3 a$ & $2 a$ & $2 a$ & $2 a$ & $2 a$ \\
\hline Rothrock grama (seedlings) & $1 \mathrm{a}$ & $0 \mathrm{a}$ & la & $0 \mathrm{a}$ & la \\
\hline
\end{tabular}

'Means in a row followed by the same letter are not significantly different $(P<0.05)$. 
period of time than in 1988, except for blue panic emergence, which was positively correlated $\left(r^{2}=0.89, P=0.016\right)$ with percentage of seeds buried above $12 \mathrm{~mm}$.

Low emergence on all treatments in 1989 was related to inconsistent rainfall and only 2-3 days of available water in the surface soil in July. More consistent rainfall and longer periods of available water occurred later in August, but these did not produce a cohort of seedlings. Seeds may have initiated germination after initial rains and desiccated during the subsequent dry periods in July. All of the seeded species have subcoleoptile internode elongation that places their adventitious roots near the soil surface and makes them susceptible to desiccation without recurrent rainfall.

Emergence of indigenous annual and short-lived perennial grasses was apparently affected much more by precipitation patterns than seedbed treatments. These grasses were not observed to emerge until after a period of consistent rainfall. Evidently they are adapted to emerge from a variety of seedbed microsites as long as soil water is available.

Analysis of past seedings is difficult because daily precipitation, temperature, humidity (Cox et al. 1982), and soil water availability are seldom measured. This study documents that seedling emergence is highly related to the pattern of soil water availability. With the exception of sideoats grama, seedling density of all species was highest during a wet year (1987), intermediate during a moderately wet year (1988), and limited during a dry year (1989). Greater seedling emergence from more disturbed seedbeds was most evident in a moderately wet year. A slightly longer period of soil water availability and increased seed burial associated with seedbed disturbance by heavy trampling, imprinting, root plowing, or ripping help to explain their higher seedling emergence compared to nondisturbance and light trampling. In this study, increased seedling emergence was more highly associated with increased percentage of seeds buried on a moderately wet year than on a wet or dry year. Seed burial may increase emergence by increasing seed-soil contact and water flow to the seed (Collis-George and Sands 1959), increasing radical penetration (Dowling et al. 1971, Cox and Martin 1984) and reducing predation (Nelson et al. 1970, Campbell and Swain 1973).

Seedling establishment of small-seeded lovegrasses may not require seedbed preparation on coarse-textured soils during wet years in southern Arizona. Sideoats grama and blue panic appear to require seedbed preparation for seedling establishment. Heavy trampling, imprinting and root plowing, or ripping all provided adequate seedbed preparation for burial and emergence during wet or moderately-wet years. During dry years these seedbed treatments would not be expected to increase seedling emergence.

\section{Literature Cited}

Allison, D.V., and C.A. Rechenthin. 1956. Root plowing proved best method of brush control in south Texas. J. Range Manage. 9:130-133. Campbell, M.H., and F.G. Swain. 1973. Factors causing losses during the establishment of surface-sown pastures. J. Range Manage. 26:355-359. Clary, W.P. 1989. Revegetation by land imprinter and rangeland drill. Res. Pap. INT-397. USDA, Forest Service Intermount. Res. Sta.
Collis, George, N.; and J.E. Sands. 1959. The control of seed germination by moisture as a soil physical property. Aust. J. Res. 10:268-636.

Colman, E.A., and T.M. Hendrix. 1949. The fiberglass electrical soilmoisture instrument. Soil Sci. 67:425-438.

Cox, J.R., M.H. Martin-R., F.A. Ibarra-F., and H.L. Morton. 1986. Establishment of range grasses on various seedbeds at creosotebush (Larrea tridentata) sites in Arizona, USA, and Chihuahua, Mexico. J. Range Manage. 39:540-546.

Cox, J.R., H.L. Morton, T.N. Johnson, Jr., G.L. Jordan, S.C. Martin, and L.C. Fierro. 1982. Vegetation restoration in the Chihuahuan and Sonoran Deserts of North America. ARM-W-28, Agr. Res. Serv. Western Region, Oakland, Calif.

Cox, J.R., and M.H. Martin. 1984. Effects of planting depth and soil texture on the emergence of four lovegrasses. J. Range Manage. 37:204-205.

Dixon, R.M., and J.R. Simanton. 1980. Land imprinting for better watershed management, p. 809-826. In: Symp. on Watershed Manage. Vol. II. 21-23 July 1980. Boise, Ida. Amer. Soc. Civil Eng.

Dowling, P.M., R.J. Clements, and J.R. McWilliam. 1971. Establishment and survival of pasture species from seeds sown on the soil surface. Aust. J. Agr. Res. 22:61-74.

Eckert, R.E., Jr., F.F. Peterson, M.S. Meurisse, and J.L. Stephens. 1986. Effects of soil-surface morphology on emergence and survival of seedlings in big sagebrush communities. J. Range Manage. 39:414-420.

Fisher, C.E., C.H. Meadors, R. Behrens, E.D. Robinson, P.T. Marion, and H.L. Morton. 1959. Control of mesquite on grazing lands. Tex. Agr. Exp. Sta. Bull. 935.

Haferkamp, M.R., D.C. Ganskopp, R.F. Miller, and F.A. Sneva. 1987. Drilling versus imprinting for establishing crested wheatgrass in the sagebrush-bunchgrass steppe. J. Range Manage. 40:524-530.

Herbel, C.H., G.H. Abernathy, C.C. Yarbrough, and D.K. Gardner. 1973. Root plowing and seeding arid rangelands in the Southwest. J. Range Manage. 26:193-197.

Hormay, A.L. 1970. Principles of rest-rotation grazing and multiple-use land management. USDI, Bur. of Land Manage.

Jordan, G.L. 1981. Range reseeding and brush management on Arizona rangelands. Bull. T81121. Arizona Agr. Exp. Sta. Univ. Ariz., Tucson.

Nelson, J.K., and S. Gabel. 1987. Initial establishment of 14 forage species on root plowed creosotebush (Larrea tridentata) rangeland in Presidio County, Texas. Tex. J. Agr. Natur. Resour. 1:49-52.

Neison, J.R., A.M. Wilson, and C.J. Goebel. 1970. Factors influencing broadcast seeding in bunchgrass range. J. Range Manage. 23:163-169.

Pearson, C.J., and R.L. Ison. 1987. Agronomy of grassland systems. Cambridge Univ. Press. Cambridge.

Plummer, P.A., A.C. Hull, Jr., G. Stewart, and J.H. Robertson. 1955. Seeding rangelands in Utah, Nevada, Southern Idaho, and Western Wyoming. USDA, Forest Service, Agr. Handb. 71.

Simanton, J.R., and G.L. Jordan. 1986. Early root and shoot elongation of selected warm-season perennial gaasses. J. Range Manage. 39:63-67.

Steel, G.D., and J.H. Torrie. 1980. Principles and procedures of statistics. Second Edition. McGraw-Hill Book Co., New York.

U.S. Dept. of Commerce, National Oceanic and Atmospheric Admin. 1987. Climatological data Arizona. National Climatic Center, Asheville, North Carolina.

Vallentine, J.F. 1989. Range development and improvements, 3rd ed. Academic Press. San Diego, Calif.

Winkel, V.K. 1990. Effects of seedbed modification, sowing depth and soil water on emergence of warm-season grasses. Ph.D. Diss., University of Arizona, Tucson.

Winkel, V.K., B.A. Roundy, and D.K. Blough. 1991. Effects of seedbed preparation and cattle trampling on burial of grass seeds. J. Range Manage. 44:171-175. 